\title{
Study of The Effect of pH on The Performance of Microbial Fuel Cell for Generation of Bioelectricity
}

\section{Md. Abdul Halim}

Department of Chemical Engineering, Jashore University of Science and Technology, Jashore-7408, Bangladesh

Md. Owaleur Rahman

Department of Chemical Engineering, Jashore University of Science and Technology, Jashore-7408, Bangladesh

\section{Md. Ibrahim}

Department of Chemical Engineering, Jashore University of Science and Technology, Jashore-7408, Bangladesh

\section{Rituparna Kundu}

Department of Chemical Engineering, Jashore University of Science and Technology, Jashore-7408, Bangladesh

\section{Biplob Biswas ( $\nabla$ bk.biswas@just.edu.bd)} Jashore University of Science and Technology https://orcid.org/0000-0002-0883-5681

\section{Research}

Keywords: Microbial fuel cell, Bioelectricity, Current density, Power density, Wastewater

Posted Date: January 22nd, 2021

DOI: https://doi.org/10.21203/rs.3.rs-151072/v1

License: (c) (i) This work is licensed under a Creative Commons Attribution 4.0 International License. Read Full License 
2 Study of the effect of $\mathrm{pH}$ on the performance of microbial fuel cell for

\section{3 generation of bioelectricity}

4

5 Md. Abdul Halim, Md. Owaleur Rahman, Md. Ibrahim, Rituparna Kundu, Biplob Kumar 6 Biswas*

7

Department of Chemical Engineering, Jashore University of Science and Technology, 9 Jashore-7408, Bangladesh

10

*Corresponding email: biplobbiswas2009@gmail.com

Abstract

Background: Day by day microbial fuel cell (MFC) technology is becoming a thoughtprovoking topic to the researcher because for its simultaneous utilization e.g. electricity production and wastewater treatment. Since wastewater is an important source of electrolyte for MFC, the key tenacity of this study was to investigate the outcome of $\mathrm{pH}$ happening various (Municipal, Bhairab river and Hospital) wastewaters used as electrolyte in dual chamber MFC.

Findings: The lab-scale experiment was conducted in batch mode, where zinc plate $\left(0.0027 \mathrm{~m}^{2}\right)$ as anode and copper plate $\left(0.0027 \mathrm{~m}^{2}\right)$ as cathode. In this study a single electrolyte (any one of earlier mentioned three electrolytes) was used in five dual-chambers MFC where the $\mathrm{pH}$ of the electrolyte was $6,7,8,9$ and 10. The MFC was worked on a temperature ranged from $27^{\circ} \mathrm{C}$ to $34^{\circ} \mathrm{C}$. Maximum outputs were found in terms of current density $\left(1288.9 \mathrm{mAm}^{-2}\right)$, voltage $(1132 \mathrm{mV})$ and power density $\left(1459.02 \mathrm{mWm}^{-2}\right)$ were 
obtained at $\mathrm{pH} 8$ by using Bhairab river water as an electrolyte in MFC chamber. A substantial amount of COD removal (94\%) was also achieved in the same MFC chamber at the same $\mathrm{pH}$ (i.e. $\mathrm{pH}$ 8). However, the optimum operating $\mathrm{pH}$ for MFC containing municipal wastewater and hospital wastewater was found to be 8 and 9 , respectively.

Conclusion: The results suggest that various wastewaters may act as feasible feedstocks for bioelectricity generation in MFC. The results also show that COD can be removed from wastewater that suggest a treatment possibility of wastewater .

Keywords: Microbial fuel cell, Bioelectricity, Current density, Power density, Wastewater.

\section{Introduction}

In contemporary years, utilization of energy in the whole world has been increased enormously (Rahimnejad et al. 2015). Energy comes from various sources such as renewable as well as non-renewable. All non-renewable (fossil) based energy has a negative impact on environment by producing greenhouse gases (Feng et al. 2018). However, for the sake of adversative effect (global heating and contamination) on the environment, the accumulation of fossil energies as a vigor source desires to be abridged (Slate et al. 2019). Considering cost effectiveness and environmental problems, an environmental friendly renewable energy source is very urgent. Microbial fuel cell is imminent system, which provides a potential renewable energy source that might help achieving energy security. MFC can produce energy (electricity) by decomposing the carbon-based substance existing in the electrolyte whereas various wastewaters as well as industrial effluents can be used. Since effluents and wastewaters are causing environmental pollution very much, their treatment is required indeed to improve the environmental condition from pollution. Apart from the classical wastewater treatment, MFC is reported to be used for wastewater management (Gotovtsev et 
al. 2016). In developed countries 1-3\% electricity for domestic consumption comes from sewage wastewater treatment plants (Maktabifard et al. 2018). At a same time MFC generate electricity and treat wastewater too (Mustakeem 2015; Dong et al. 2015). Variety of knowledge from engineering, biology and chemistry is required for the assembly and finest procedure of microbial fuel cells (Mansoorian et al. 2014; Rajeswari et al. 2016). The most three key materials of MFC are electrode, membrane, and electrolyte which, determine the performance of the MFCs. In MFC bio-electrochemical both half-cell reactions occurs on the outward of the anode and cathode. However, better yield optimization and improvement of electrode of MFC are still thought-provoking research topic worldwide (Li et al. 2017). Ion exchange membrane (IEMs) particular cation exchange membrane (CEM) is very effective on large-scale with greater depth of electrolyte (Ge and He 2016; Liang et al. 2018). Though, the MFC can extravagances numerous cations, such for example $\mathrm{Na}^{+}, \mathrm{Ca}^{2+}, \mathrm{K}^{+}$, and $\mathrm{NH}_{4}^{+}$ present in the electrolyte (wastewater), which contest by protons that attribute to the minus charged functional groups in the CEM (Rozendal et al. 2006), which can reduce in electrical energy creation subsequently long-standing process (Ge and He 2016; Liang et al. 2018). Bacteria can help to increase the output of MFC and reject mediator from anode chamber (Reshetilov et al. 2017). Literature shows that, electrolytes like chemical based industrial wastewater (Venkata Mohan et al. 2008), dairy wastewater (Porwal et al. 2015), soak liquor (Sawasdee and Pisutpaisal 2016), dye factory wastewater (Kalathil et al. 2012; Patade et al. 2016), starch treating wastewater (Quan et al. 2014), leachate (Damiano et al. 2014), sugar mill sewage (Kumar et al. 2016), Domestic wastewater (Asai et al. 2017), Poultry dropping wastewater (Oyiwona et al. 2018), rice bran (Takahashi et al. 2016) beside through new spreads in the usage of various substrates (Pandey et al. 2016) can be treated by MFC. Beside wastewater MFC can usage clean mixtures such as acetate or butyrate (Hidalgo et al. 2016), alcohol, fatty acid, monosaccharide sugar (Asensio et al. 2016), sucrose and glucose as 
electrolyte. To improve the output of MFC, recently researchers did several studies to the practice of MFC through membrane (Ghasemi et al. 2015), short of membrane (Logan et al. 2007), using moderator, short of moderator (Sevda and Sreekrishnan 2012) also using biocathodes (Gonzalez del Campo et al. 2014). Various operating parameters such as pH (Jadhav and Ghangrekar 2009), anode and cathode ingredients (Scott et al. 2008), the space among the electrodes (Hong et al. 2009a), external resistance (Hong et al. 2009a), temperature (Hong et al. 2009a), conductivity (Hong et al. 2009b), also carbon-based substance of the deposit (Wang et al. 2012) distresses the generated outputs of the microbial fuel cell.

The foremost interest of our experiment is to examine the effect of initial $\mathrm{pH}$ of various wastewaters obtained from Jashore on the output of MFC and to find the most favorable value of $\mathrm{pH}$ at which the system works best. To achieve that several experiments on municipal wastewater, bhairab river water and hospital wastewater were conducted by using zinc plate as anode, copper plate as cathode, and salt bridge as proton exchange membrane.

\section{Materials and Methods}

In this section, design and construction procedures of MFC are discussed with detailed description of construction materials. The reactor configuration and operation of the whole processes (micro-organism inoculation, electrolyte collection, salt bridge and electrode preparation, data collection and performance analysis) are also discussed.

\section{Materials collection and cell construction}

Various materials were used for this research work. Each material has its specific function. However, the coordinated function of these materials is to construct microbial fuel cell and to 
Table 1 Name and function of ingredients used in microbial fuel cell. 1.
104

operate it optimally. The name and its operation of the used ingredients are given in the Table

\begin{tabular}{ll}
\hline Name & Function \\
\hline Zinc plate and Copper plate & Anode and Cathode \\
Glass & Body of MFC \\
PVC pipe, Potassium sulphate salt, Agar-agar & Constituents for salt bridge \\
and Surgical cloth & \\
Waste water & Electrolyte \\
Digital Multimeter & Collecting data
\end{tabular}

Zinc and Copper plates (for anode and cathode) were purchased from local scientific shop at Jashore, Bangladesh. All other items were purchased from local shops. To construct the main body (the chamber) of the MFC, locally available window glass was used. The volume of each chamber was $0.005 \mathrm{~m}^{3}$ (length $0.25 \mathrm{~m}$, width $0.10 \mathrm{~m}$ and height $0.20 \mathrm{~m}$ ) where there were three intros; single designed for adding, second for deletion of electrolyte as well as rest one for the connection with former compartment. The two chambers were connected using an agar salt bridge with a length and diameter of $4.0 \mathrm{~cm}$ and $0.5 \mathrm{~cm}$, separately. For the preparation of salt bridge $0.1 \mathrm{M}$ salt solution of $5 \mathrm{gm}$ agar was prepared in which several pieces of surgical cloths were kept for 2-3 h. A small PVC tube approximately $4.0 \mathrm{~cm}$ long was packed by the surgical cloths immersed the agar-salt resolutions. All joints of MFC were enclosed using M-seal (K1 Mart, India) to avert the outflow. The prepared microbial fuel cell (MFC) is shown in Fig. 1. 

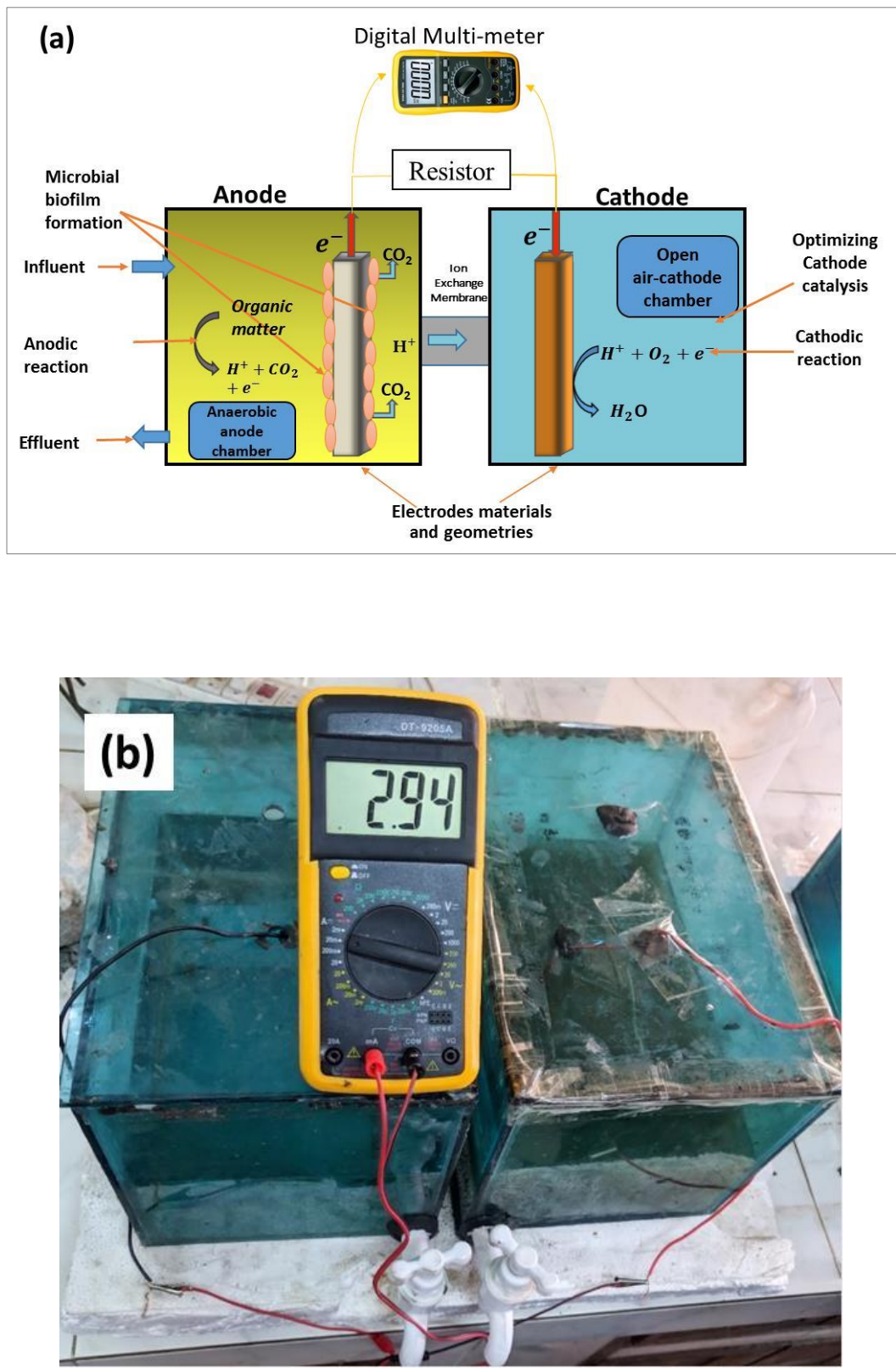

122 Fig. 1(a) Schematic diagram and (b) constructed MFC for the experiment.

124 Microbe inoculation and electrolyte collection

125 Locally available microorganisms (Escherichia coli, Anabaena, Rhodospirillum and some 126 cyanobacteria) were used in all experiment. At first organic rich bottom feeders were 127 collected from the local pond, which was then cultured for proper growth of micro-organisms.

128 It was done by mixing $1.5(\mathrm{~W} / \mathrm{w} \%)$ cow dung and $0.2(\mathrm{~W} / \mathrm{w} \%)$ sugar with bottom feeders. 
129 The mixture was kept in an anaerobic condition for $48 \mathrm{~h}$. After inoculation these microbes were used in anode chamber for the experiment. The untreated raw wastewaters (collected

131 from Municipal drain, Bhairab River and Jashore General Hospital) were used in anode 132 chamber. For first experiment we collected wastewater from municipal drain where the water 133 flow rate was $225 \mathrm{ml} \cdot \mathrm{s}^{-1}$. In second experiment we collected wastewater from Bhairab River at $150 \mathrm{~cm}$ depth from the surface. In third experiment we collected wastewater from Jashore General Hospital pipeline where the water flow rate was $195 \mathrm{ml} \cdot \mathrm{s}^{-1}$. The average chemical compositions of these wastewaters throughout the experiment are abridged in Table 2. The average COD concentration of the raw municipal wastewater was $784 \mathrm{mg} \cdot \mathrm{L}^{-1}$, Bhairab river water was $832 \mathrm{mg} \cdot \mathrm{L}^{-1}$ and hospital wastewater was $842 \mathrm{mg} \cdot \mathrm{L}^{-1}$.

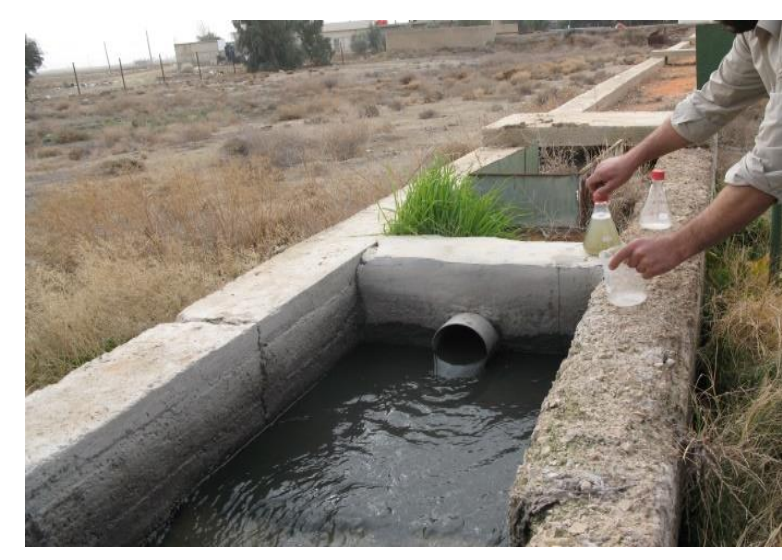

(a) Municipal drainage

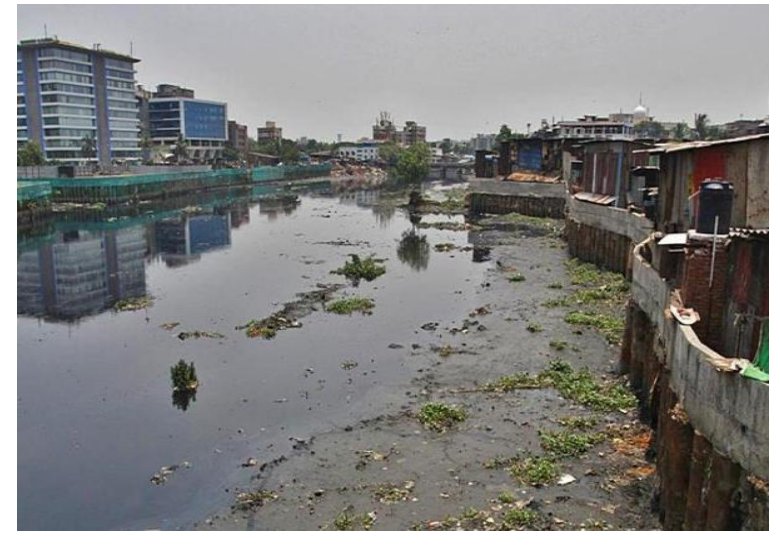

(b) Bhairab river

Fig. 2 Sources of wastewater used as electrolyte.

Table 2: The average chemical composition of various wastewaters in Jashore, Bangladesh.

\begin{tabular}{cccc}
\hline Parameter & $\begin{array}{c}\text { Municipal } \\
\text { wastewater }\left(\mathbf{m g} \cdot \mathbf{L}^{-\mathbf{1}}\right)\end{array}$ & $\begin{array}{c}\text { Bhairab river } \\
\text { water }\left(\mathbf{m g} \cdot \mathbf{L}^{-\mathbf{1}}\right)\end{array}$ & $\begin{array}{c}\text { Hospital wastewater } \\
\left(\mathbf{m g} \cdot \mathbf{L}^{-\mathbf{1}}\right)\end{array}$ \\
\hline $\mathrm{HCO}_{3}^{-}$ & 347.4 & 354.8 & 294.6 \\
$\mathrm{Cl}^{-}$ & 395.8 & 565.6 & 835.3 \\
$\mathrm{Ca}^{2+}$ & 32.4 & 38.6 & 56.6
\end{tabular}




$\begin{array}{cccc}\mathrm{Mg}^{2+} & 26.7 & 32.3 & 18.7 \\ \mathrm{Na}^{+} & 17.3 & 21.9 & 19.9 \\ \mathrm{NO}_{3}^{-} & 4.42 & 3.24 & 13.18 \\ \mathrm{SO}_{4}^{2-} & 82.3 & 87.5 & 127.5 \\ \mathrm{PO}_{4}^{2-} & 6.25 & 5.8 & 3.9\end{array}$

142

143 Collection of data and its analysis

144 To monitor the effect of electrode materials, data was collected manually by using a digital 145 multi-meter (DT-9205A, China) at a fixed interval of $20 \mathrm{~min}$. The average values of voltage 146 and current were calculated as follows:

$$
\begin{aligned}
& \text { Average voltage }=\text { Total voltage } / \text { Number of count } \\
& \text { Average current }=\text { Total current } / \text { Number of count }
\end{aligned}
$$

147 Founded on the documented electrical energy (voltage, current and power) current density $148\left(I_{\text {anode }}, \mathrm{A} \cdot \mathrm{m}^{-2}\right)$ as well as power density $\left(P_{\text {anode }}, \mathrm{W} \cdot \mathrm{m}^{-2}\right)$ were determined as follows:

$$
\begin{aligned}
& \text { Current density, } \mathrm{I}_{\text {anode }}=\mathrm{I} / \mathrm{A} \\
& \text { Power density, } \mathrm{P}_{\text {anode }}=\mathrm{P} / \mathrm{A}
\end{aligned}
$$

where, $I$ is current (A), $P$ is the power (W), and $A$ is the external area $\left(\mathrm{m}^{2}\right)$ of the anode.

\section{Calculation of COD removal}

152 Chemical Oxygen Demand (COD) specifies the quantity of oxygen $\left(\mathrm{O}_{2}\right)$ that can be consumed by reactions in a measured solution. The carbon-based substance existing in the water sample is dissolved by potassium dichromate $\left(\mathrm{K}_{2} \mathrm{Cr}_{2} \mathrm{O}_{7}\right)$ in the attendance of sulfuric acid $\left(\mathrm{H}_{2} \mathrm{SO}_{4}\right)$, silver sulfate $\left(\mathrm{Ag}_{2} \mathrm{SO}_{4}\right)$ and mercury sulfate $\left(\mathrm{HgSO}_{4}\right)$ to harvest carbon dioxide $\left(\mathrm{CO}_{2}\right)$ and water $\left(\mathrm{H}_{2} \mathrm{O}\right)$. COD can be calculated by using Equation 5. 


$$
\mathrm{COD}=\frac{8 \times 1000 \times \mathrm{DF} \times \mathrm{M} \times\left(\mathrm{V}_{\mathrm{B}}-\mathrm{V}_{\mathrm{S}}\right)}{\text { Volume of sample }(\text { in } \mathrm{ml})}
$$

157 where, DF stands for the Dilution Factor, M stands for the Molarity of standardized Ferrous

158 Ammonium Sulfate $\left(\mathrm{NH}_{4}\right)_{2} \mathrm{Fe}\left(\mathrm{SO}_{4}\right)_{2} \cdot 6 \mathrm{H}_{2} \mathrm{O}$ solution, $\mathrm{V}_{\mathrm{B}}$ stands for the Volume used up in titration through blank preparation, $\mathrm{V}_{\mathrm{S}}$ stands for the Volume used up in titration through sample preparation.

To calculate the removal percentage of COD we used the Equation 6.

$$
\begin{aligned}
& \text { COD removal efficiency (\%) } \\
& \qquad=\frac{C O D_{\text {in }}-C O D_{\text {out }}}{C O D_{\text {in }}} \times 100
\end{aligned}
$$

Where, subscript in and out indicates influent and effluent fluid, respectively.

\section{Results and discussion}

Parameters such as pH (Jadhav and Ghangrekar 2009), electrode constituents (Scott et al. 2008), the space among the electrodes (Hong et al. 2009a), external resistance (Hong et al. 2009a), temperature (Hong et al. 2009a), conductivity (Hong et al. 2009b), also biological matter of the residue (Wang et al. 2012) are reported to affect the power production of the microbial fuel cell. The performance of MFCs increased for long term operation when electro-genic biofilm formed on the electrode surface. The $\mathrm{pH}$ of electrolytes acting a vigorous character in bioreactor performance (Gil et al. 2003). Likewise, electrolyte pH acting a vigorous key role in MFC's power output. Acidic pH lower than 6 drastically reduces the power generated from MFC (Gil et al. 2003). It means, low-slung pH situations exposed a contrary consequence on the electro-chemically lively bacteriological inhabitants, which in chance clues to an extreme fall in power generation. So, $\mathrm{pH}$ strongly influences the output of MFC for both in batch feed and continuous feed way of action. A perfect $\mathrm{pH}$ variety 
for favored fuel cell arrangement was quantified to be in the mid of 7-8 (Liu and Ramnarayanan 2004). This section mainly discussed the effect of $\mathrm{pH}$ on various locally available wastewaters for the output of microbial fuel cells.

\section{Effect of pH while using municipal wastewater as electrolyte}

In microbial fuel cell operation, $\mathrm{pH}$ is considered to be an important parameter that may affect the generation of electricity. A series of experiments were conducted by varying the $\mathrm{pH}$ (from $\mathrm{pH} 6$ to $\mathrm{pH} \mathrm{10)}$ of the electrolyte (municipal wastewater in this case) while the other parameters such as operating temperature, volume of the electrolyte, materials of electrodes, surface area of electrodes etc. were kept constant. The results are depicted in Fig. 3 (a, b and c). As shown in Fig. 3(a), it was obvious that $\mathrm{pH} 8$ gave highest output (in the form of voltage) all through the experimental period ( 1 - 15 days) compared to other experimented $\mathrm{pH}$. The voltage gradually increased up to day 4 and then it started to decline. The highest value of voltage $(1125 \mathrm{mV})$ was obtained at day 4 for the process operated at $\mathrm{pH} 8$. On the other hand, current density increases up to day 3 for all tested $\mathrm{pH}$ as shown in Fig. 3 b. Then it starts decreasing gradually. However, the maximum value of current density was found to be $1155.6 \mathrm{mAm}^{-2}$ for $\mathrm{pH} 8$ at day 3. Like voltage and current density the supreme power density was obtained at $\mathrm{pH} 8$ which is $1245.7 \mathrm{mWm}^{-2}$, where the other top values are 1008.7 $\mathrm{mWm}^{-2}, 1066.8 \mathrm{mWm}^{-2}, 990.9 \mathrm{mWm}^{-2}$ and $837.8 \mathrm{mWm}^{-2}$ for $\mathrm{pH} 6,7,9$ and 10 , respectively as shown in Fig. 3 (c). It is obvious from Fig. 3(a, b and c) that voltage, current density and power density increases for first several days and then starts to decrease gradually. The increase in extent of current density, voltage and power density in initial days happens because (Abhilasha 2013) shows that microbial inoculation enabled higher current yield. In this experiment it takes three to four days for complete inoculation of bacteria. Again the decrease in extent may happen owing to the fact that with time a biofilm may form on the 
exterior of the anode. However after 15 days of operation, cumulative yields for voltage, current density and power density were tabulated in Table 3 from where it is obvious that $\mathrm{pH}$ 8 showed highest values.

206

Table 3: Cumulative yield obtained from municipal wastewater for various $\mathrm{pH}$ in 15 days using microbial fuel cell (MFC).

\begin{tabular}{|c|c|c|}
\hline Operating pH & Measurement & Cumulative value \\
\hline \multirow[t]{3}{*}{6} & Voltage $(\mathrm{mV})$ & 12497 \\
\hline & Current density $\left(m A m^{-2}\right)$ & 11014.8 \\
\hline & Power density $\left(m W m^{-2}\right)$ & 9518.8 \\
\hline \multirow[t]{3}{*}{7} & Voltage $(\mathrm{mV})$ & 12847 \\
\hline & Current density $\left(m A m^{-2}\right)$ & 11918.5 \\
\hline & Power density $\left(m W m^{-2}\right)$ & 10551.1 \\
\hline \multirow[t]{3}{*}{8} & Voltage (mV) & 13577 \\
\hline & Current density $\left(m A m^{-2}\right)$ & 13574.1 \\
\hline & Power density $\left(m W m^{-2}\right)$ & 12676.2 \\
\hline \multirow[t]{3}{*}{9} & Voltage (mV) & 12050 \\
\hline & Current density $\left(m A m^{-2}\right)$ & 11151.8 \\
\hline & Power density $\left(m W m^{-2}\right)$ & 9298.1 \\
\hline \multirow[t]{3}{*}{10} & Voltage $(\mathrm{mV})$ & 11455 \\
\hline & Current density $\left(m A m^{-2}\right)$ & 9829.6 \\
\hline & Power density $\left(m W m^{-2}\right)$ & 7830.4 \\
\hline
\end{tabular}



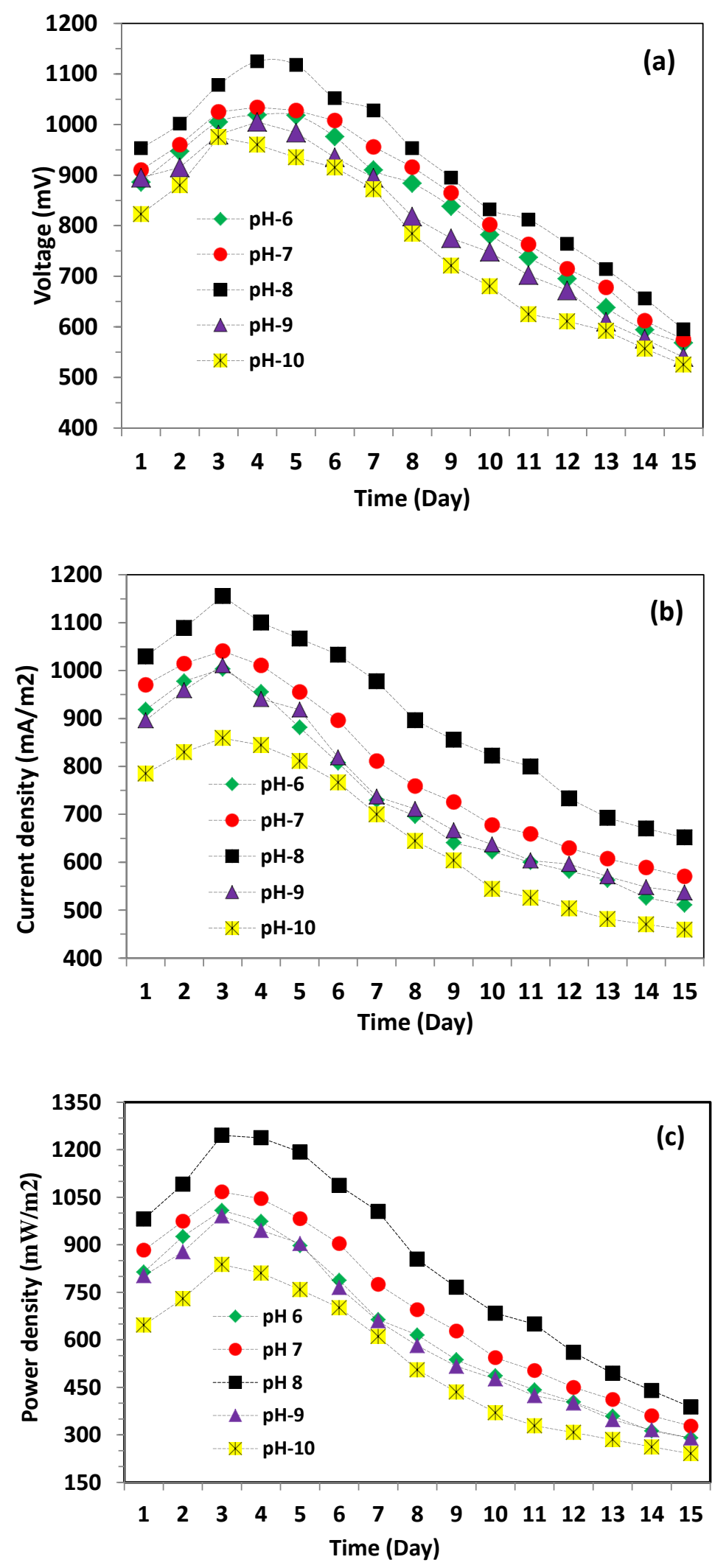

211 Figure 3: Effect of various pH on the (a) generated voltage, (b) current density and (c) power density from double chamber MFC for municipal wastewater. 
214 For comparison with other reported values, a comparative statement has been tabulated in

215 Table 4. It is apparent that the present study gives better result in terms of extent of voltage,

216 current density and power density compared to many other reported values.

217

218 Table 4: Comparative statement with related published research findings.

\begin{tabular}{|c|c|c|c|c|c|c|}
\hline pH & Electrode & $\begin{array}{l}\text { Electrolyt } \\
\text { e }\end{array}$ & Voltage & $\begin{array}{l}\text { Current/ } \\
\text { Current } \\
\text { density }\end{array}$ & $\begin{array}{l}\text { Power/ } \\
\text { Power } \\
\text { density }\end{array}$ & Reference \\
\hline 8 & $\begin{array}{l}\text { Zinc and } \\
\text { copper }\end{array}$ & $\begin{array}{l}\text { Municipal } \\
\text { wastewater }\end{array}$ & $1125 \mathrm{mV}$ & $\begin{array}{l}1155.6 \\
m A m^{-2}\end{array}$ & $\begin{array}{l}1245.7 \\
m W m^{-2}\end{array}$ & $\begin{array}{l}\text { Present } \\
\text { study }\end{array}$ \\
\hline & $\begin{array}{l}\text { copper boride } \\
\text { alloy }\end{array}$ & $\begin{array}{l}\text { Municipal } \\
\text { wastewater }\end{array}$ & & $\begin{array}{l}3500 \\
m A m^{-2}\end{array}$ & $\begin{array}{l}3055 \\
m W m^{-2}\end{array}$ & $\begin{array}{l}\text { Paweł and } \\
\text { Barbara } \\
2019\end{array}$ \\
\hline 6.9 & $\begin{array}{l}\text { carbon paper } \\
\text { and } \\
\text { magnesium } \\
\text { oxide }\end{array}$ & $\begin{array}{l}\text { Sugar } \\
\text { industry } \\
\text { wastewater }\end{array}$ & $1420 \mathrm{~m} \mathrm{~V}$ & $23.66 \mathrm{~mA}$ & $5.1 \mathrm{mWm}^{-2}$ & $\begin{array}{l}\text { Omprakash } \\
2019\end{array}$ \\
\hline 7 & graphite felt & & $445 \mathrm{mV}$ & & & $\begin{array}{l}\text { Zhang et al. } \\
2011\end{array}$ \\
\hline $6-7$ & graphite felt & & & $400 \mu \mathrm{A}$ & & $\begin{array}{l}\text { Biffinger et } \\
\text { al. } 2008\end{array}$ \\
\hline
\end{tabular}


graphite felt
$m A m^{-2}$
2008
graphite rod urban
$18 \mathrm{mWm}^{-2} \quad$ Sebastia et
wastewater
al. 2010

He et al.
219

220

221

222

223

224

225

226

227

228

229

230

231

232

233

234

235

236

237

This findings is very much resemble with (Jadhav and Ghangrekar 2009), who express that highest current is obtained between $\mathrm{pH}$ of 6.5 and 8 , but this values were lesser at $\mathrm{pH}$ of 9 plus $\mathrm{pH}$ under 7 . The main reason behind this, at higher $\mathrm{pH}$ than optimum value affects the growth of bacteria, which decrease he generated voltage (Sebastia et al. 2010).

COD removal is an important parameter for microbial fuel cell. (Zinadini et al. 2017) indicates that high COD deletion and columbic efficiency (CE) improve significantly the productivity of MFCs. The initial COD of municipal waste water in Jashore municipality was $538 \mathrm{ppm}$. In this experiment the COD removal were over $86 \%, 89 \%, 91 \%, 88 \%$ and $86 \%$ for

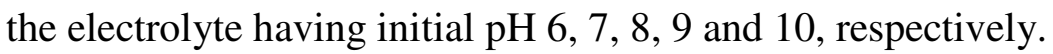

\section{Effect of pH while using Bhairab river water as electrolyte}

A series of experiments were conducted by varying the $\mathrm{pH}$ (from $\mathrm{pH} 6$ to $\mathrm{pH} 10$ ) of the electrolyte (Bhairab river water in this case) while the other parameters such as operating temperature, volume of the electrolyte, materials of electrodes, surface area of electrodes etc. were kept constant. Water collected at $150 \mathrm{~cm}$ depth from the surface of the river water. The results are depicted in Fig. 4(a), 4(b) and 4(c). As shown in Fig. 4(a), it was obvious that $\mathrm{pH} 8$ gave highest output (in the form of voltage) all through the experimental period ( $1-15$ days) 
compared to other experimented $\mathrm{pH}$. The voltage gradually increased up to day 4 and then it started to decline. The highest value of voltage $(1132 \mathrm{mV})$ was obtained at day 4 for the process operated at $\mathrm{pH} 8$. It is also seen in (Fig. 4a) that, in operation period $\mathrm{pH} 8$ gives the best result in all time. The yield from $\mathrm{pH} 7$ is better than the other three. Obtained voltage 242 from $\mathrm{pH} 6$ and $\mathrm{pH} 9$ are approximately the same, but for higher $\mathrm{pH}$ (10) the yield is lower than the others. Like voltage, current density (Fig. 4b) spike in first four days goes a maximum value of $1144.4 \mathrm{mAm}^{-2}, 1174.1 \mathrm{mAm}^{-2}, 1288.9 \mathrm{mAm}^{-2}, 1181.5 \mathrm{mAm}^{-2}$, and 1122.2 $\mathrm{mAm}^{-2}$ for $\mathrm{pH} 6,7,8,9$ and 10 , respectively, and then current density decreased in a similar way to voltage. In this experiment the maximum current density obtained for $\mathrm{pH} 8$.

Similar to voltage and current density the supreme power density obtained for $\mathrm{pH} 8$ which is $1459.02 \mathrm{mWm}^{-2}$, where the other top values are $1199.4 \mathrm{mWm}^{-2}, 1272.7 \mathrm{mWm}^{-2}$, $1250 \mathrm{mWm}^{-2}$ and $1120 \mathrm{mWm}^{-2}$ for $\mathrm{pH} 6,7,9$ and 10, correspondingly which is shown in Fig. 4c. It shows that for maximum output $\mathrm{pH} 8$ is better than the other, so, it can be said that, when Bhairab river water is used as electrolyte $\mathrm{pH} 7$ to $\mathrm{pH} 8$ produce the better yield. Variation of $\mathrm{pH}$ from this value the outlet will be declined. The total obtained values are shown in Table 5.

Table 5: Cumulative yield obtained from Bhairab river water for various $\mathbf{p H}$ in $\mathbf{1 5}$ days using microbial fuel cell (MFC).

\begin{tabular}{lll}
\hline Operating pH & Measurement & Cumulative value \\
\hline 6 & Voltage $(\mathrm{mV})$ & 13145 \\
& Current density $\left(\mathrm{mAm}^{-2}\right)$ & 12566.7 \\
& Power density $\left(\mathrm{mWm}^{-2}\right)$ & 11435.4 \\
\hline
\end{tabular}




\begin{tabular}{|c|c|c|}
\hline \multirow[t]{3}{*}{7} & Voltage $(\mathrm{mV})$ & 13729 \\
\hline & Current density $\left(m A m^{-2}\right)$ & 13274.1 \\
\hline & Power density $\left(m W m^{-2}\right)$ & 12526.3 \\
\hline \multirow[t]{3}{*}{8} & Voltage (mV) & 14597 \\
\hline & Current density $\left(m A m^{-2}\right)$ & 15322.2 \\
\hline & Power density $\left(m W m^{-2}\right)$ & 15233.5 \\
\hline \multirow[t]{3}{*}{9} & Voltage (mV) & 13424 \\
\hline & Current density $\left(m A m^{-2}\right)$ & 13740.7 \\
\hline & Power density $\left(m W m^{-2}\right)$ & 12644.02 \\
\hline \multirow[t]{3}{*}{10} & Voltage (mV) & 12577 \\
\hline & Current density $\left(m A m^{-2}\right)$ & 12966.7 \\
\hline & Power density $\left(m W m^{-2}\right)$ & 11202.7 \\
\hline
\end{tabular}

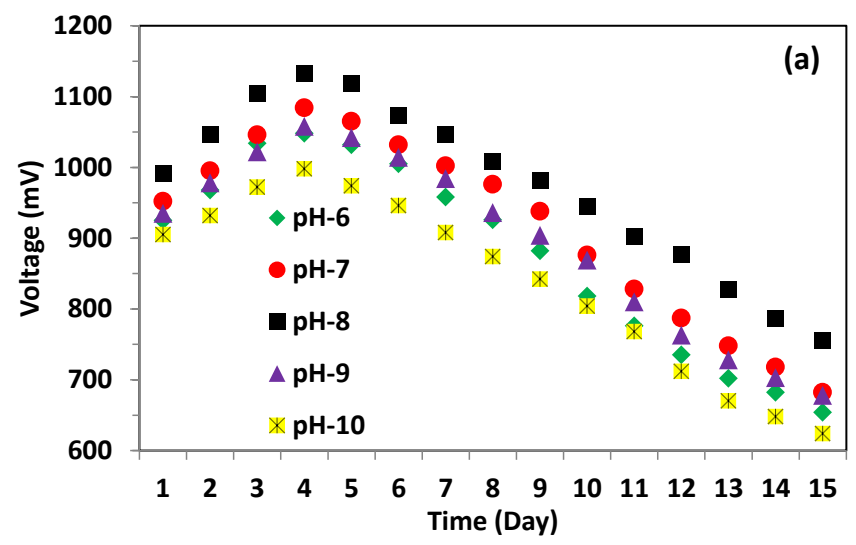



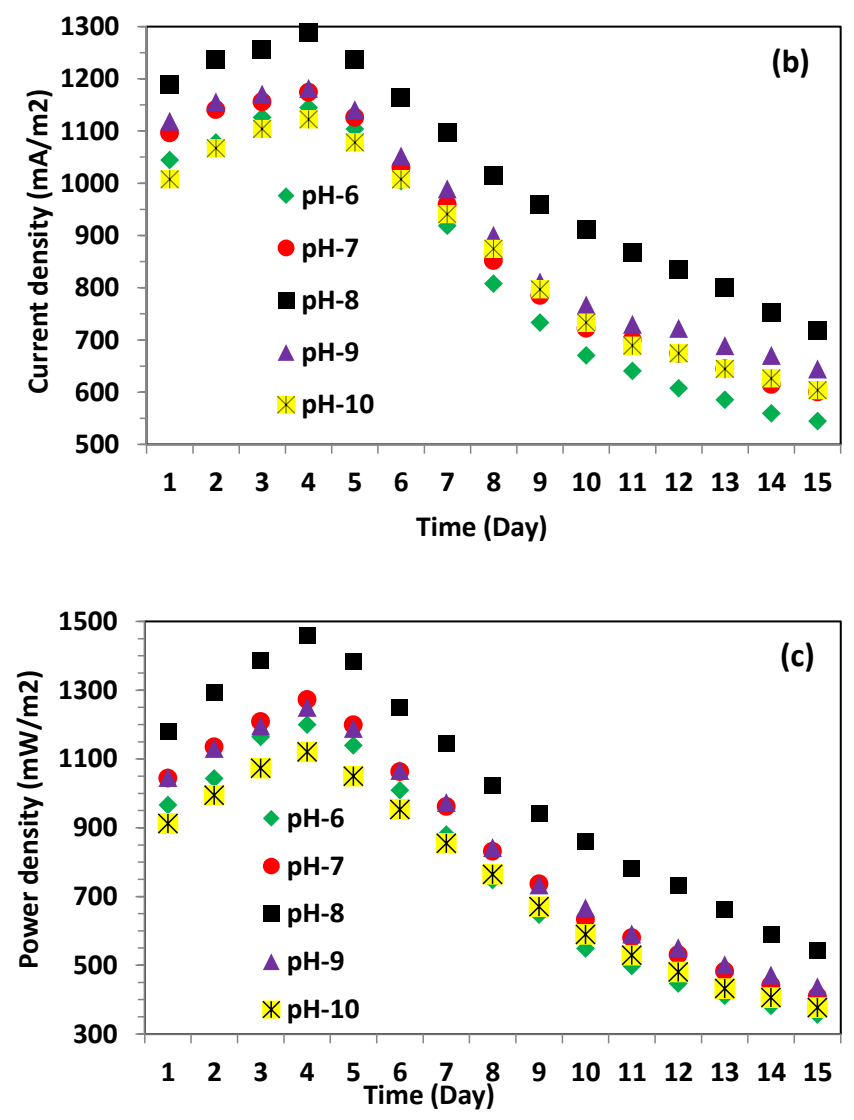

Figure- 4: Effect of various $\mathrm{pH}$ on the (a) generated voltage, (b) current density, (c) power density from double chamber MFC for bhairab river wastewater.

For comparison with other reported values, a comparative statement has been tabulated in

Table 6. It is apparent that the present study gives better result in terms of extent of voltage, current density and power density compared to many other reported values.

Table 6: Comparative statement with related published research findings.

\begin{tabular}{|c|c|c|c|c|c|c|}
\hline pH & Electrode & Electrolyte & Voltage & $\begin{array}{l}\text { Current } \\
\text { density }\end{array}$ & $\begin{array}{l}\text { Power } \\
\text { density }\end{array}$ & Reference \\
\hline 8.0 & Zinc and copper & $\begin{array}{l}\text { Bhairab } \\
\text { river water }\end{array}$ & $\begin{array}{l}1132 \\
\mathrm{mV}\end{array}$ & $\begin{array}{l}1288.9 \\
m A m^{-2}\end{array}$ & $\begin{array}{l}1459.02 \\
m W m^{-2}\end{array}$ & This study \\
\hline
\end{tabular}


6

graphite

rods and $\mathrm{PbO}_{2}$

graphite

6.5 to Carbon cloth

7.5

6.7 Hybrid with

stainless steel and

Musi river $\mathrm{mV}$

water

Domestic
River water $937 \mathrm{mV} \quad 382$

$\left(\mu \mathrm{A} / \mathrm{cm}^{2}\right)$

86

Dhiraj et al.

wastewater

120

$\mathrm{Li}$ and

$m W m^{-2}$

Chen 2018

plain graphite
267

268

269

270

271

272

273

In fifteen days operation the COD removal were over $88 \%, 90 \%, 94 \%, 91 \%$ and $89 \%$ for the electrolyte having initial $\mathrm{pH} \mathrm{6,7,8,9}$ and 10 respectively. COD removal rates of (Zhang et al. 2011) were $85 \%, 86 \%, 83 \%$, and $88 \%$ at initial $\mathrm{pH}(4,5,6$, and 7$)$ respectively. We got all the maximum findings at $\mathrm{pH}$ 8. (Zhang et al. 2011) also said that, on anode surface biofilms formed by both long and short rod-shaped biomass bacteria. But acidic medium the thickness of biofilm is less than the neutral medium. So, biofilms can break at $\mathrm{pH} \leq 5$, which can drop down into the inner portion of the electrode, resulting in decries the generated electricity. (Behera et al. 2010) identified that; slightly alkaline anodic $\mathrm{pH}$ (7.5) is favorable for better electricity generation and COD removal. (Gil et al. 2003) said that at higher $\mathrm{pH}$ more than 10 power generations decreased for low proton transfer.

\section{Effect of pH while using Jashore General Hospital wastewater as electrolyte}

To examine the consequence of $\mathrm{pH}$ on the output of microbial fuel cell, several experiments were done by using Jashore General Hospital wastewater as electrolyte. The experiment 
performed at room temperature and Zinc plate used as an anode and Cupper plate used as a cathode. In this experiment, the only variable was the initial $\mathrm{pH}$ (6 to 10) of electrolyte. Whereas, the other operating conditions (temperature, volume, electrolyte, and electrode) are the same. Here the Jashore General Hospital wastewater was collected from the outlet of hospital pipeline. The results are depicted in Fig. 5a, 5b and 5c. As shown in Fig. 5a, it was obvious that $\mathrm{pH} 9$ gave highest output (in the form of voltage) all through the experimental period (1-15 days) compared to other experimented $\mathrm{pH}$. The voltage gradually increased up to day 4 and then it started to decline. The highest value of voltage $(1016 \mathrm{mV})$ was obtained at day 4 for the process operated at $\mathrm{pH} 9$. Again, in current density it increases up to day 4 for all tested $\mathrm{pH}$ as shown in Fig. 5b. Then it starts decreasing gradually. However, the maximum value of current density was found to be $1007.41 \mathrm{mAm}^{-2}$ for $\mathrm{pH} 9$ at day 4 . Like voltage and current density the extreme power density was obtained at $\mathrm{pH} 9$ which is $1023.53 \mathrm{mWm}^{-2}$, where the other top values are $767.31 \mathrm{mWm}^{-2}, 830.27 \mathrm{mWm}^{-2}, 980.71 \mathrm{mWm}^{-2}$ and $886.5 \mathrm{mWm}^{-2}$ for $\mathrm{pH} 6,7,8$ and 10, respectively as shown in Fig. 5c. All the figures show that, for Jashore General Hospital wastewater as electrolyte $\mathrm{pH} 9$ is better than the other. Where, (Parkash 2018) got pick output at $\mathrm{pH}$ 8.5. Variation of $\mathrm{pH}$ from this value the outlet will be declined. The total obtained values are shown in Table 7.

Table 7 Cumulative yield obtained from Jashore General Hospital wastewater for various pH in 15 days using microbial fuel cell (MFC).

\begin{tabular}{lll}
\hline Operating pH & Measurement & Cumulative value \\
\hline 6 & Voltage $(\mathrm{mV})$ & 11827 \\
& Current density $\left(\mathrm{mAm}^{-2}\right)$ & 8529.63 \\
& Power density $\left(\mathrm{mWm}^{-2}\right)$ & 7072.72
\end{tabular}


Current density $\left(m A m^{-2}\right)$

8977.78

Power density $\left(m W m^{-2}\right)$

7597.98

8

Voltage (mV)

12575

Current density $\left(\mathrm{mAm}^{-2}\right) \quad 10370.37$

Power density $\left(\mathrm{mWm}^{-2}\right) \quad 9039.91$

9

Voltage (mV)

12989

Current density $\left(\mathrm{mAm}^{-2}\right) \quad 10874.07$

Power density $\left(\mathrm{mWm}^{-2}\right) \quad 9732.85$

10

Voltage (mV)

12286

Current density $\left(\mathrm{mAm}^{-2}\right)$

9477.78

Power density $\left(m W m^{-2}\right)$

8119.42

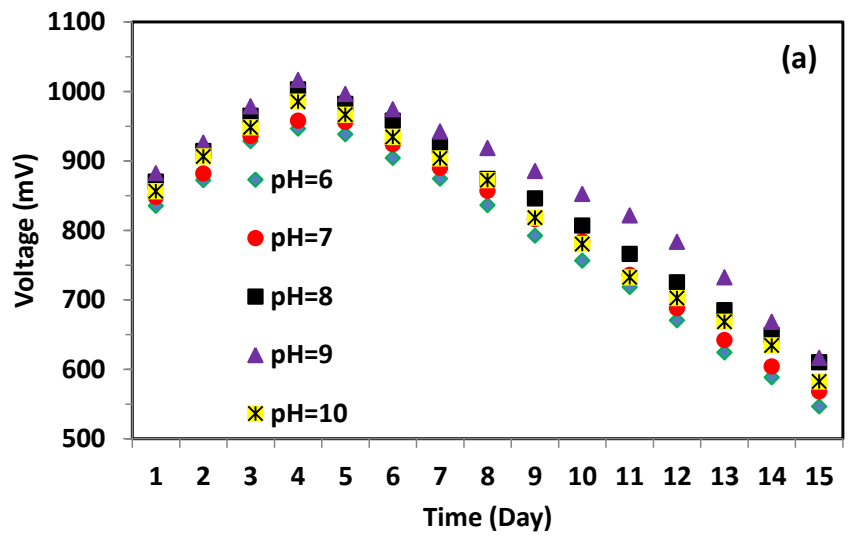



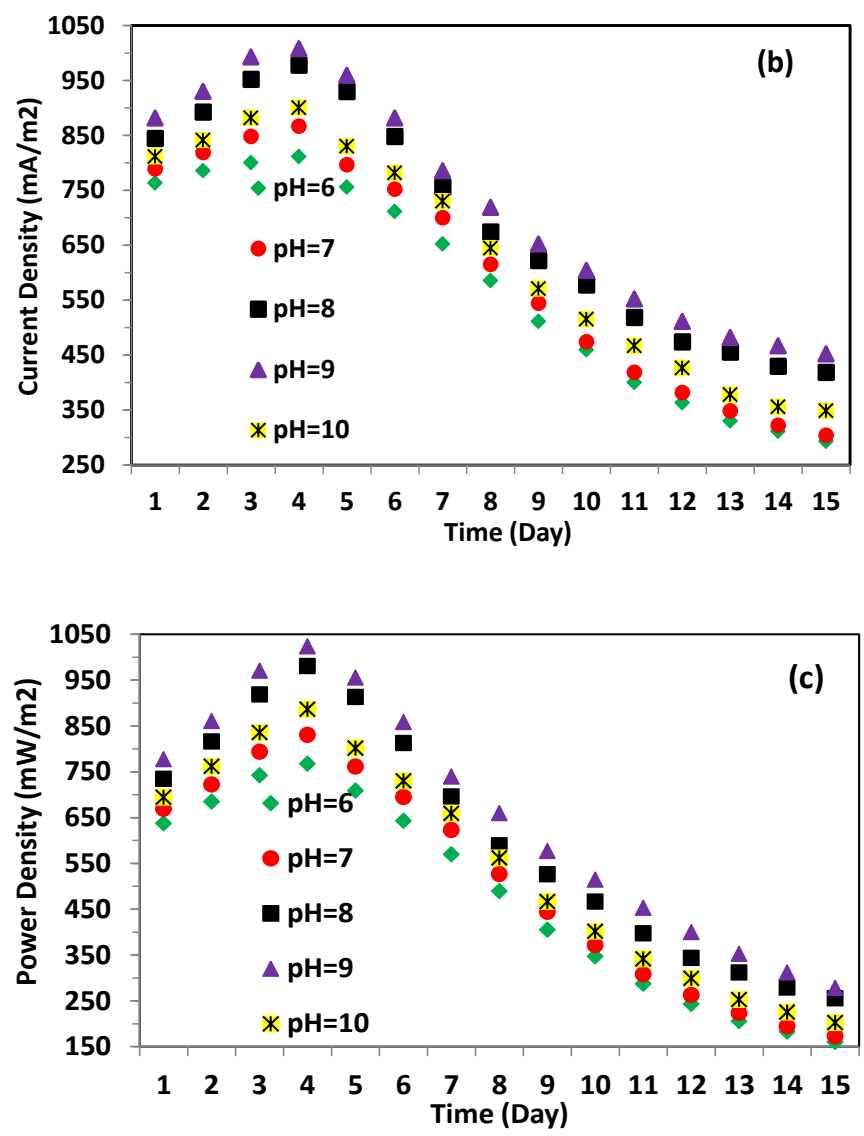

307 For comparison with other reported values, a comparative statement has been tabulated in

Table 8 Comparative statement with related published research findings.

\begin{tabular}{lllllll}
\hline pH & Electrode & Electrolyte & Voltage & Current & Power & Reference \\
& & & & density & density & \\
\hline 8.0 & Zinc and copper & Jashore & 1016 & 1007.41 & 1023.53 & This \\
& & General & $\mathrm{mV}$ & $\mathrm{mAm} \mathrm{m}^{-2}$ & $\mathrm{mWm}^{-2}$ & experiment
\end{tabular}




\section{Hospital}

wastewater

7.5 Graphite granules

and graphite rod wastewater

$140 \pm 10 \quad$ Aelterman

Hospital

$m W m^{-2} \quad$ et al. 2006

9.0 Graphite felt and

$439.7 \pm \quad 231.3 \pm 1.1 \quad 107.1 \pm 1.0 \quad$ He et al.

carbon cloth

$0.1 \mathrm{mV} \quad m A m^{-2} \quad m W m^{-2} \quad 2008$

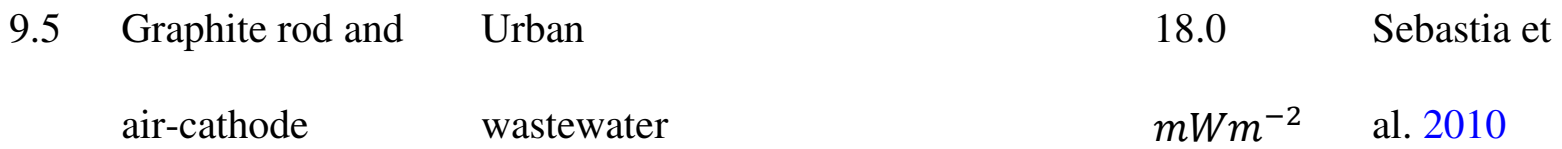

313 COD removal is very significant to treat wastewater. Higher COD removal means the process

314 is more applicable for wastewater treatment. In fifteen days operation the COD removal were over $78 \%, 83 \%, 86 \%, 88 \%$ and $84 \%$ for the electrolyte having initial $\mathrm{pH} 6,7,8,9$ and 10 respectively.

\section{Conclusion}

Initial $\mathrm{pH}$ greatly affects the output of microbial fuel cell along with COD removal from wastewater. In every experiment initially the productivity (voltage, current density and power density) increased then after a certain period these values gradually decreased with time. The main reason behind this anodic microbe took time for their proper growth, after complete inoculation the growth of microbes is decreased. The optimum $\mathrm{pH}$ for municipal waste water of Jashore and bhairab river water is 8.0 , where the maximum voltage, current density and power density were $1125 \mathrm{mV}, 1155.6 \mathrm{mAm}^{-2}, 1245.7 \mathrm{mWm}^{-2}$ and $1132 \mathrm{mV}$, 
$3261288.9 \mathrm{mAm}^{-2}, 1459.02 \mathrm{mWm}^{-2}$ respectively. But for hospital wastewater the top results

327 obtained at $\mathrm{pH} 9$ these were $1016 \mathrm{mV}, 1007.41 \mathrm{mAm}^{-2}$ and $1023.53 \mathrm{mWm}^{-2}$. The 328 maximum COD removal was $91 \%, 94 \%$ and $88 \%$ from municipal, bhairab river and hospital 329 wastewater respectively. At lower $\mathrm{pH}$ anodic biofilm will break which result the lower 330 output.

331

332 Declarations

333

334 Ethics approval and consent to participate

335 Not applicable.

336

337 Consent for publication

338 Not applicable.

339

340

Availability of data and materials

341

All data generated through experiments and analyzed during this study are included in this

342 article.

343

344

Competing interests

345 The authors declare that they have no competing interests.

346

$347 \quad$ Funding

348 Not applicable.

349

350 Authors' contributions 
MAH conceptualized the methodology, wrote original draft, MOR gave general advice, MI

352

353

354

355

356

357

358

359

360

361

362

363

364

365

366

367

368

369

370

371

372

373

designed and conducted the experiments, RK designed and conducted the experiments, and BKB laid the guideline, edited and reviewed the manuscript. All authors read and approved the final manuscript.

\section{Acknowledgement}

Not applicable.

\section{Authors' information}

Department of Chemical Engineering, Jashore University of Science and Technology, Jashore-7408, Bangladesh.

\section{References}

Abhilasha SM (2013) Inoculum selection to enhance performance of a microbial fuel cell for electricity generation during wastewater treatment. Environ Technol 34:1957-1964. https://doi.org/10.1080/09593330.2013.808674

Aelterman P, Rabaey K, Clauwaert P, Verstraete W (2006) Microbial fuel cells for wastewater treatment. Water Sci Technol 54(8):9-15. https://doi.org/10.2166/wst.2006.702

Asai Y, Miyahara M, Kouzuma A, and Watanabe K, (2017), Comparative evaluation of wastewater-treatment microbial fuel cells in terms of organics removal, waste-sludge production, and electricity generation, Bioresour Bioprocess, 4(1), https://doi.org/10.1186/s40643-017-0163-7 
Asensio Y, Fernandez-Marchante CM, Lobato J, Canizares P, Rodrigo MA (2016) Influence of the fuel and dosage on the performance of double-compartment microbial fuel cells. Water Res 99:16-23. https://doi.org/10.1016/j.watres.2016.04.028

Behera M, Jana PS, More TT, Ghangrekar MM (2010) Rice mill wastewater treatment in microbial fuel cells fabricated using proton exchange membrane and earthen pot at $\begin{array}{lll}\text { different } & \mathrm{pH} & \text { Bioelectrochem }\end{array}$ 79:228-233. https://doi.org/10.1016/j.bioelechem.2010.06.002

Biffinger JC, Little B, Pietron J, Ray R, Ringeisen BR (2008) Aerobic Miniature Microbial Fuel Cells. NRL Review 141-142

Damiano L, Jambeck JR, Ringelberg DB (2014) Municipal solid waste landfill leachate treatment and electricity production using microbial fuel cells. Appl Biochem Biotechnol 173:472-485. https://doi.org/10.1007/s12010-014-0854-X

Dhiraj C, Vijay J, Harish KD, and Datta K (2020) Influence of microbial fuel cell employed with porous anode on the voltage generation, $\mathrm{COD}$, chloride content and total dissolved solids. Water Sci Technol. https://doi.org/10.2166/wst.2020.380

Dong Y, Feng Y, Qu Y, Du Y, Zhou X, Liu J (2015) A combined system of microbial fuel cell and intermittently aerated biological filter for energy self-sufficient wastewater treatment. Sci Rep 5:1-8. https://doi.org/10.1038/srep1 8070

Feng T, Zhou W, Wu S, Niu Z, Cheng P, Xiong X, Li G (2018) Simulations of summertime fossil fuel $\mathrm{CO} 2$ in the Guanzhong basin. Sci Total Environ 624:1163-70. https://doi.org/10.1016/j.scitotenv.2017.12.021

Ge Z, He Z (2016) Long-term performance of a 200 liter modularized microbial fuel cell system treating municipal wastewater: treatment, energy, and cost. Environ Sci Water Res Technol 2:274-281. https://doi.org/10.1039/c6ew00020g 
Ghasemi M, Halakoo E, Sedighi M, Alam J, Sadeqzadeh M (2015) Performance comparison of three common proton exchange membranes for sustainable bioenergy production in microbial fuel cell. Procedia CIRP 26:162-166. https://doi.org/10.1016/j.proci r.2014.07.169

Gil GC, Chang IS, Kim BH, Kim M, Jang JK, Park HS, Kim HJ (2003) Operational parameters affecting the performance of a mediator-less microbial fuel cell. Biosens Bioelectron 18(4):327-334. https://doi.org/10.1016/s0956-5663(02)00110-0

Gonzalez del Campo A, Perez JF, Cañizares P, Rodrigo MA, Fernandez FJ, Lobato J (2014) Study of a photosynthetic MFC for energy recovery from synthetic industrial fruit juice wastewater. Int J Hydrog Energy 39:21828-21836. https://doi.org/10.1016/j.ijhydene.2014.07.055

Gotovtsev P, Dyakov A (2016) Biotechnology and Internet of Things for green smart city application 2016 IEEE 3rd World Forum on Internet of Things (WF-IoT) 542-6.

He Z, Huang Y, Manohar AK, Mansfeld F (2008) Bioelectrochemistry Effect of electrolyte $\mathrm{pH}$ on the rate of the anodic and cathodic reactions in an air-cathode microbial fuel cell. Bioelectrochemistry 74(1):78-82. https://doi.org/10.1016/j.bioelechem.2008.07.007

Hidalgo D, Tommasi T, Velayutham K, Ruggeri B (2016) Long term testing of microbial fuel cells: comparison of different anode materials. Bioresour Technol, 219:37-44. https://doi.org/10.1016/j.biort ech.2016.07.084

Hong SW, Chang IS, Choi YS, Chung TH (2009) Experimental evaluation of influential factors for electricity harvesting from sediment using microbial fuel cell. Bioresour Technol 100 (12):3029-3035. https://doi.org/10.1016/j.biortech.2009.01

Hong SW, Chang IS, Choi YS, Kim BH, Chung TH (2009) Responses from freshwater sediment during electricity generation using microbial fuel cells. Bioprocess Biosyst Eng 32(3):389-395. https://doi.org/10.1007/s00449-008-0258-9 
Jadhav G, Ghangrekar M (2009) Performance of microbial fuel cell subjected to variation in $\mathrm{pH}$, temperature, external load and substrate concentration. Bioresour Technol 100(2):717-723. https://doi.org/10.1016/j.biortech.2008.07.041

Kalathil S, Lee J, Cho MH (2012) Efficient decolorization of real dye wastewater and bioelectricity generation using a novel single chamber biocathode-microbial fuel cell. Bioresour Technol 119:22-27. https://doi.org/10.1016/j.biort ech.2012.05.059

Kumar R, Singh L, Zularisam AW (2016) Exoelectrogens: recent advances in molecular drivers involved in extracellular electron transfer and strategies used to improve it for microbial fuel cell applications. Renew Sustain Energy Rev 56:1322-1336. https://doi.org/10.1016/j.rser.2015.12.029

Li S, Chen G (2018) Factors Affecting the Effectiveness of Bioelectrochemical System Applications: Data Synthesis and Meta-Analysis. Batteries 4(3):34. https://doi.org/10.3390/batteries4030034

Li S, Cheng C, Thomas A (2017) Carbon-based microbial-fuel cell electrodes: from conductive supports to active catalysts. Adv Mater 29:1602547. https://doi.org/10.1002/adma.201602547

Liang P, Duan R, Jiang Y, Zhang X, Qiu Y, Huang X (2018) One-year operation of 1000-L modularized microbial fuel cell for municipal wastewater treatment. Water Res 141:18. https://doi.org/10.1016/j.watres.2018.04.066

Liu H, Ramnarayanan R (2004) Production of Electricity during Wastewater Treatment Using a Single Chamber Microbial Fuel Cell. Environ Sci Technol 38(7):2281-2285. https://doi.org/10.1021/es034923g

Logan B, Cheng S, Watson V, Estadt G (2007) Graphite fiber brush anodes for increased power production in air-cathode microbial fuel cells. Environ Sci Technol 41:33413346. https://doi.org/10.1021/es062644y 
Maktabifard M, Zaborowska E, Makinia J (2018) Achieving energy neutrality in wastewater treatment plants through energy savings and enhancing renewable energy production. Rev Environ Sci Biotechnol 17:655-689. https://doi.org/10.1007/s11157-018-9478-X

Mansoorian HJ, Mahvi AH, Jafari AJ, Khanjani N (2014) Evaluation of dairy industry wastewater treatment and simultaneous bioelectricity generation in a catalyst-less and mediator-less membrane microbial fuel cell. J SAUDI CHEM SOC 20:88-100. https://doi.org/10.1016/j.jscs.2014.08.002

Mustakeem (2015) Electrode materials for microbial fuel cells: nanomaterial approach. Mater Renew Sustain Energy 4:1-11. https://doi.org/10.1007/s4024 3-015-0063-8

Omprakash S (2019) Sustainable and clean treatment of industrial wastewater with microbial fuel cell. Engineering. https://doi.org/10.1016/j.rineng.2019.100053

Oyiwona1G E, Ogbonna J C, Anyanwu C U and Okabe S, (2018), Electricity generation potential of poultry droppings wastewater in microbial fuel cell using rice husk charcoal electrodes, Bioresour Bioprocess, 5(1), https://doi.org/10.1186/s40643-018-0201-0

Pandey P, Shinde VN, Deopurkar RL, Kale SP, Patil SA, Pant D (2016) Recent advances in the use of different substrates in microbial fuel cells toward wastewater treatment and simultaneous energy recovery. Appl Energy 168:706-723. https://doi.org/10.1016/j.apene rgy.2016.01.056

Parkash A (2018) Effects of various parameters on bioenergy generation in microbial fuel $\begin{array}{llll}\text { cell. } & \text { MOJ } & \text { Proteomics } & \text { Bioinform } 177-178 .\end{array}$ https://doi.org/10.15406/mojpb.2018.07.00229

Patade S, Silveira K, Babu A, Mhatre Y, Saini V, Rajput R, Mathew J, Birmole R (2016) Bioremediation of dye effluent waste through an optimised microbial fuel cell. Int J Adv Res Biol Sci 3:214-226 
472 Paweł PW, Barbara W (2019) Wastewater Treatment and Electricity Production in a Microbial Fuel Cell with $\mathrm{Cu}-\mathrm{B}$ Alloy as the Cathode Catalyst. Catalysts 9:572. https://doi.org/10.3390/catal9070572

Porwal HJ, Mane AV, Velhal SG (2015) Biodegradation of dairy effluent by using microbial isolates obtained from activated sludge. Water Resour Ind 9:1-15. https://doi.org/10.1016/j.wri.2014.11.002

Puig S, Serra M, Coma M, Cabré M, Balaguer M, Colprim J (2010) Effect of pH on nutrient dynamics and electricity production using microbial fuel cells. Bioresour Technol 101: 9594-9. https://doi.org/10.1016/j.biortech.2010.07.082.

Quan X, Tao K, Mei Y, Jiang X (2014) Power generation from cassava alcohol wastewater: effects of pretreatment and anode aeration. Bioprocess Biosyst Eng 37:2325-2332. https://doi.org/10.1007/s0044 9-014-1210-9

Rahimnejad M, Adhami A, Darvari S, Zirepour A, Oh SE (2015) Microbial fuel cell as new technology for bioelectricity generation: a review. Alex Eng J 54:745-756. https://doi.org/10.1016/j. aej.2015.03.031

Rajeswari S, Vidhya S, Navanietha Krishnaraj R, Saravanan P, Sundarapandiyan S, Maruthamuthu S, Ponmariappan S, Vijayan M (2016) Utilization of soak liquor in microbial fuel cell. Fuel 181:148-156. https://doi.org/10.1016/j.fuel.2016.04.121

Reshetilov A, Plekhanova Yu, Tarasov S, Arlyapov V, Kolesov V, Gutorov M, Gotovtsev P, Vasilov R (2017) Effect of some carbon nanomaterials on ethanol oxidation by Gluconobacteroxydans bacterial cells. Appl Biochem and Microbiol 53:123-9. https://doi.org/10.1134/S0003683817010161

Rozendal RA, Hamelers HVM, Buisman CJN (2006) Effects of membrane cation transport on $\mathrm{pH}$ and microbial fuel cell performance. Environ Sci Technol 40:5206-5211. https://doi.org/10.1021/es060387r 
Sawasdee V, Pisutpaisal N (2016) Simultaneous pollution treatment and electricity generation of tannery wastewater in air-cathode single chamber MFC. Int J Hydrog Energy 41:15632-15637. https://doi.org/10.1016/j.ijhyd ene.2016.04.179

Scott K, Cotlarciuc I, Head I, Katuri KP, Hall D, Lakeman JB, Browning D (2008) Fuel cell power generation from marine sediments: investigation of cathode $\begin{array}{lllll}\text { materials. } & \text { J } & \text { Chem 83(9):1244-1254. }\end{array}$ https://doi.org/10.1002/jctb.1937

Sevda S, Sreekrishnan TR (2012) Effect of salt concentration and mediators in salt bridge microbial fuel cell for electricity generation from synthetic wastewater. J Environ Sci Health A Tox Hazard Subst Environ Eng 47:878-886. https://doi.org/10.1080/10934529.2012.665004

Slate AJ, Whitehead KA, Brownson DAC, Banks CE (2019) Microbial fuel cells: an overview of current technology. Renew Sustain Energy Rev 101:60-81. https://doi.org/10.1016/j.rser.2018.09.044

Takahashi S, Miyahara M, Kouzuma A, and Watanabe K, (2016), Electricity generation from rice bran in microbial fuel cells, Bioresour Bioprocess, 3:50. https://doi.org/10.1186/s40643-016-0129-1

Venkata Mohan S, Mohanakrishna G, Reddy BP, Saravanan R, Sarma PN (2008) Bioelectricity generation from chemical wastewater treatment in mediatorless (anode) microbial fuel cell (MFC) using selectively enriched hydrogen producing mixed culture under acidophilic microenvironment. Biochem Eng J 39:121-130. https://doi.org/10.1016/j.bej.2007.08.023

Venkata Mohan S, Srikanth S, Raghuvulu S, Mohanakrishna G, Kumar AK, Sarma PN, (2009) Evaluation of the potential of various aquatic eco-systems inharnessing bioelectricity through benthic fuel cell: effect of electrode assembly and water 

https://doi.org/10.1016/j.biortech.2008.10.020

524
Wang A, Cheng H, Ren N, Cui D, Lin N, Wu W (2012) Sediment microbial fuel cell with floating biocathode for organic removal and energy recovery. Front Environ Sci Eng In China 6(4):569-574. https://doi.org/10.1007/s11783-011-0335-1

Zhang L, Li C, Ding L, Xu K, Ren H (2011) Influences of initial pH on performance and anodic microbes of fed-batch microbial fuel cells. J Chem Technol Biotechnol 86(9):1226-1232. https://doi.org/10.1002/jctb.2641

Zinadini S, Zinatizadeh AA, Rahimi M, Vatanpour V, Rahimi Z (2017) High power generation and COD removal in a microbial fuel cell operated by a novel sulfonated PES/PES blend proton exchange membrane. Energy 125:427-438. https://doi.org/10.1016/j.energy.2017.02.146 
Figures
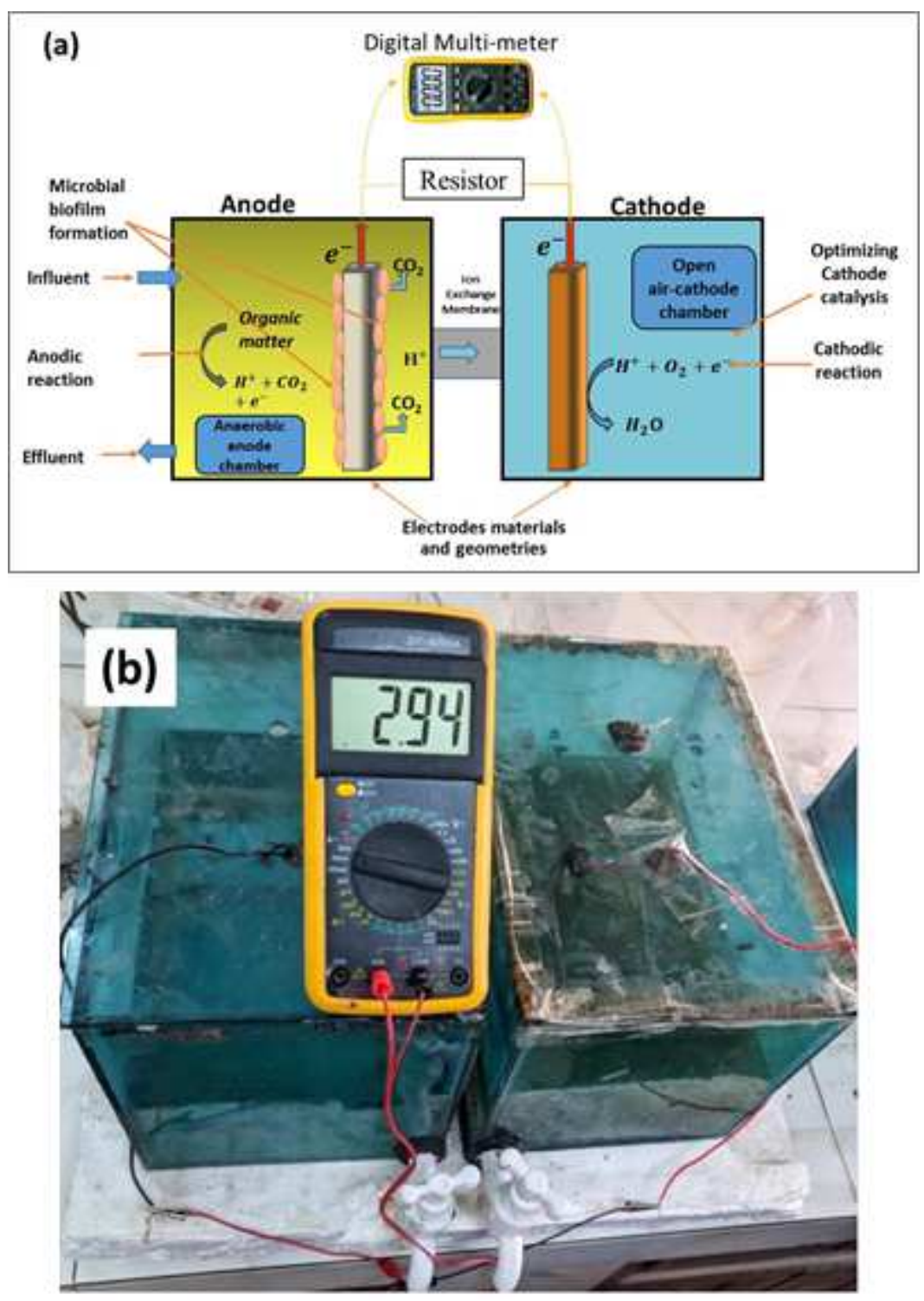

Figure 1

(a) Schematic diagram and (b) constructed MFC for the experiment. 


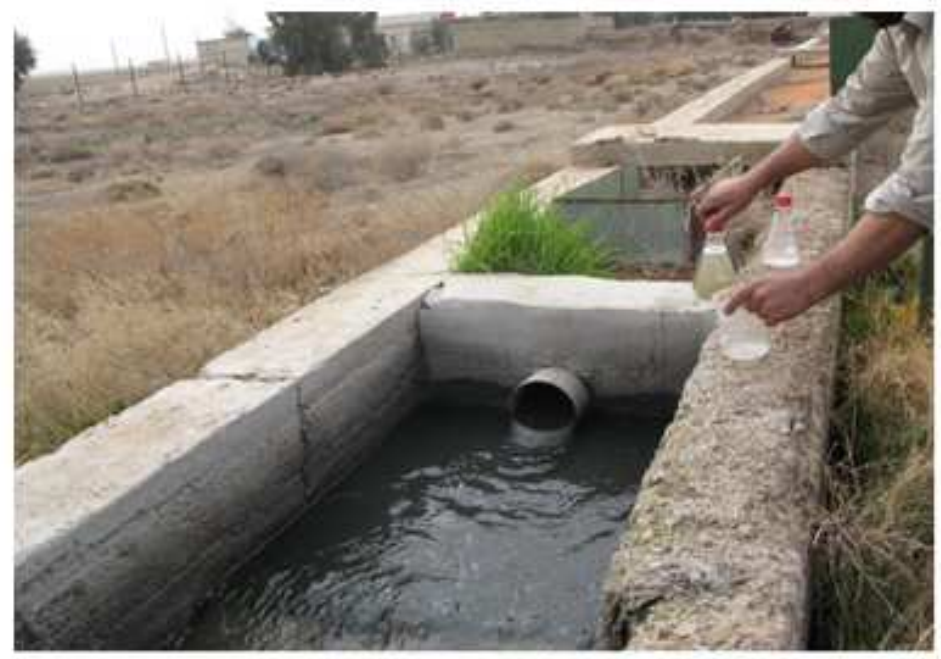

(a) Municipal drainage

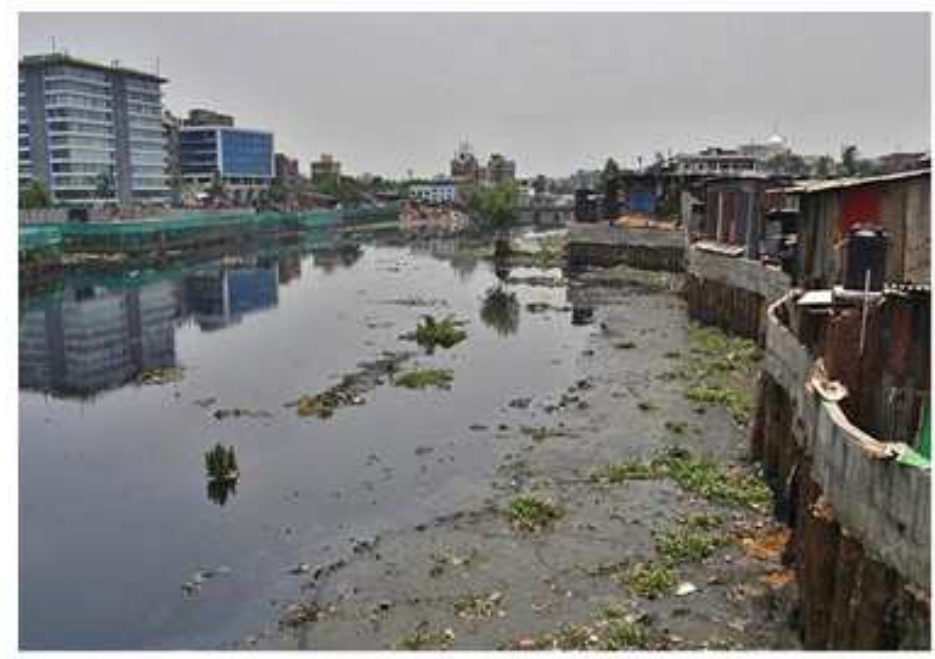

(b) Bhairab river

Figure 2

Sources of wastewater used as electrolyte. 

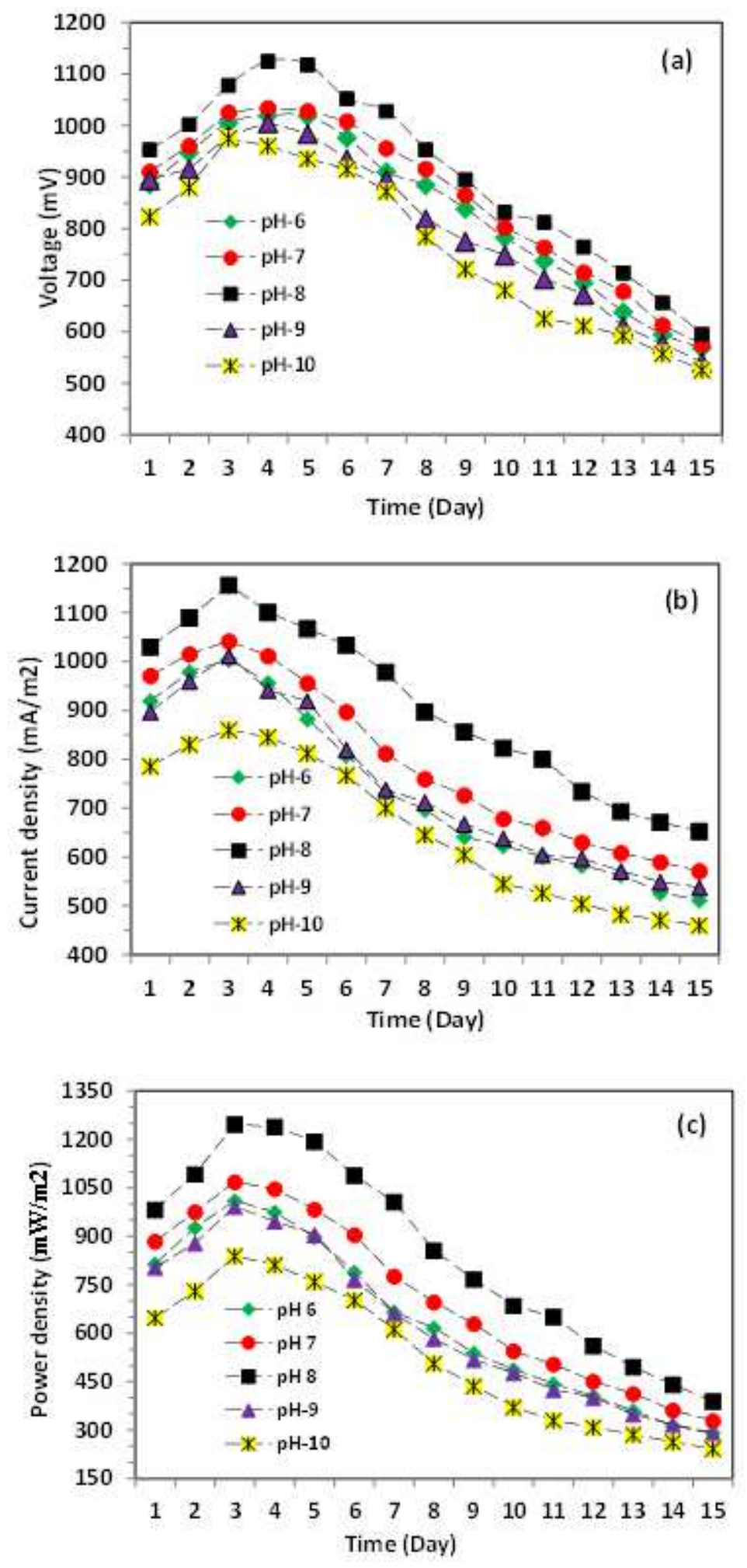

\section{Figure 3}

Effect of various $\mathrm{pH}$ on the (a) generated voltage, (b) current density and (c) power density from double chamber MFC for municipal wastewater. 

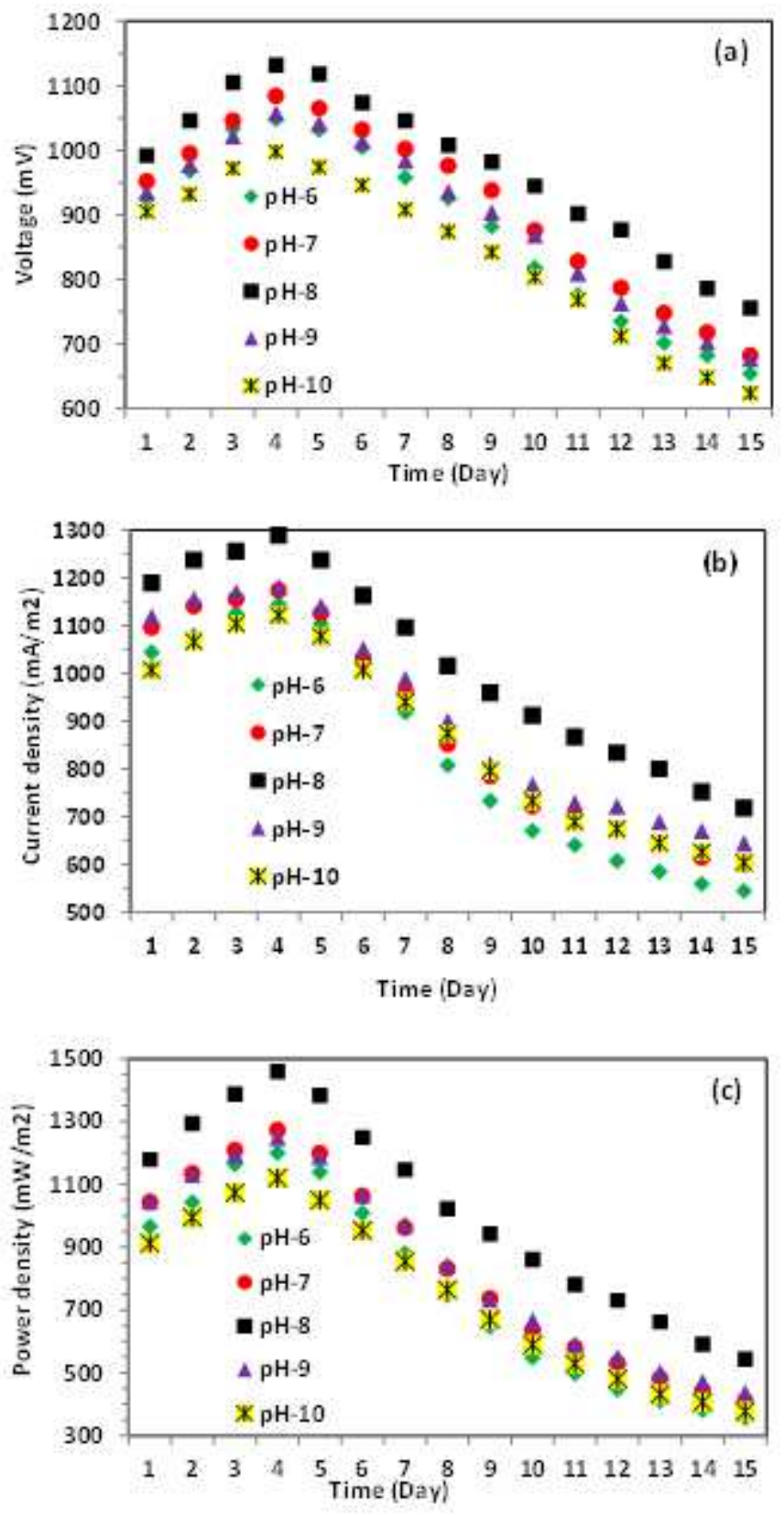

Figure 4

Effect of various $\mathrm{pH}$ on the (a) generated voltage, (b) current density, (c) power density from double chamber MFC for bhairab river wastewater. 

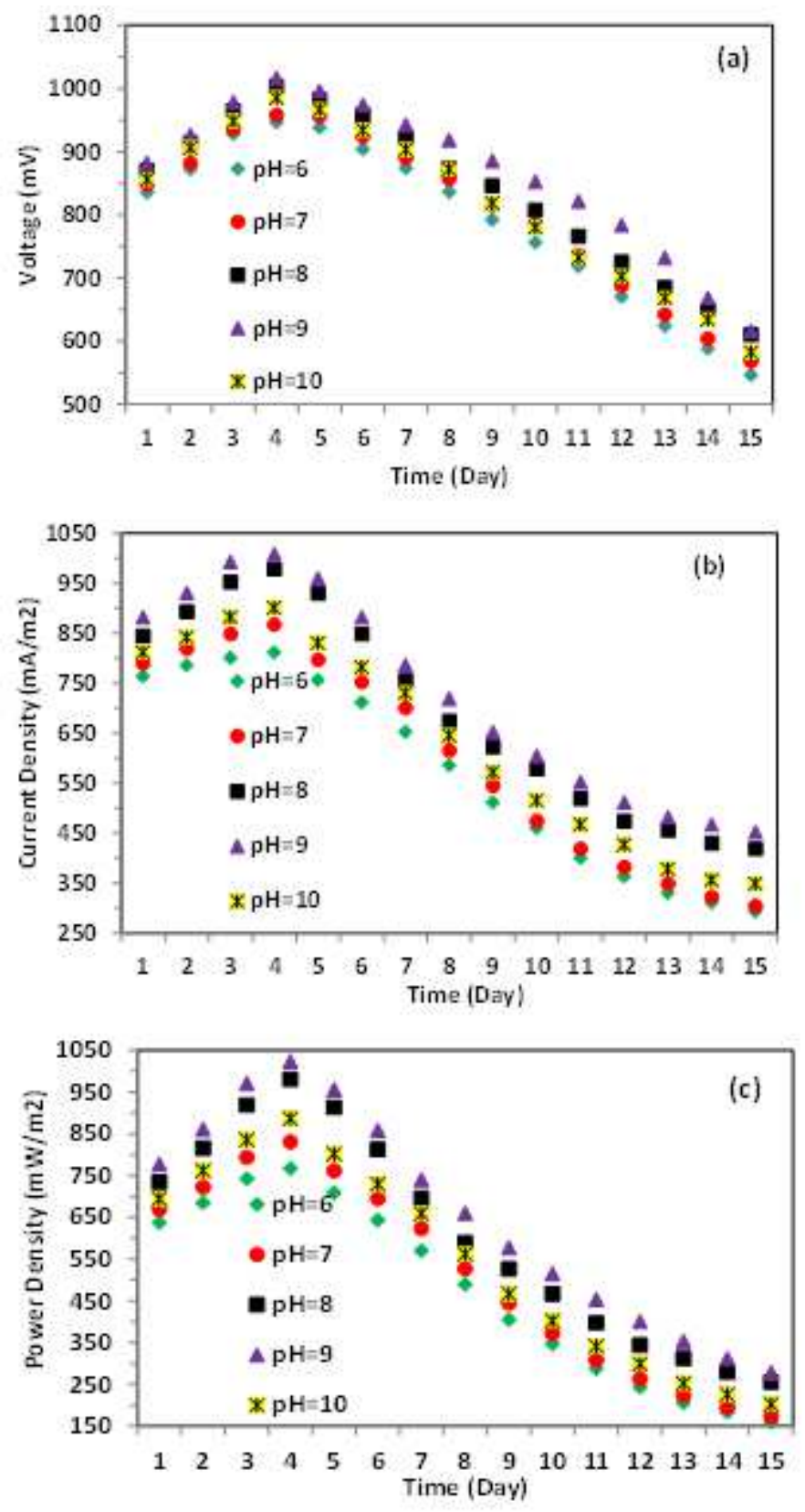

Figure 5

Effect of various $\mathrm{pH}$ on the (a) generated voltage, (b) current density, (c) power density from double chamber MFC for Jashore General Hospital wastewater.

\section{Supplementary Files}

This is a list of supplementary files associated with this preprint. Click to download.

- Graphicalabstract.docx 